\title{
Morphological characterization of Achai cattle in sedentary and transhumant systems in Pakistan
}

\author{
M. Saleem ${ }^{1}$, I. Rahim ${ }^{2}$, S. Jalali ${ }^{3}$, H. Rueff ${ }^{4,5}$, M. Khan ${ }^{1}$, D. Maselli' ${ }^{2}, U^{2}$. Wiesmann ${ }^{5}$ and S. Muhammad ${ }^{1}$ \\ ${ }^{1}$ Directorate General (Extension) Livestock and Dairy Development Khyber Pakhtunkhwa, Peshawar, Pakistan; ${ }^{2}$ Mountain Society \\ Research Centre, University of Central Asia, Bishkek, Kyrgyzstan; ${ }^{3}$ Department of Animal Sciences, Quaid-i-Azam University \\ Islamabad, Islamabad, Pakistan; ${ }^{4}$ School of Geography and the Environment, University of Oxford, South Parks Road, Oxford, OXI \\ 3QY, United Kingdom; ${ }^{5}$ Centre for Development and Environment, University of Bern, Hallerstrasse 10, 3012 Bern, Switzerland
}

\begin{abstract}
Summary
Achai is an as yet undocumented but well-adapted cattle breed of the Hindu Kush Mountains of northern Pakistan, which is reared under sedentary farming system (SFS) and transhumant farming system (TFS). This paper compares the morphological (physical and morphometric) characteristics of this cattle breed under both farming systems to know the effect of these styles of management. Data were collected from 108 adult females and 108 males in SFS and 108 females and 36 males in TFS on physical characteristics (colour of the coat, horns, eyelashes, muzzle, hoof, switch) and morphometric measurements - i.e. heart girth, body length, height at withers, height at hipbone, face length, horn length, horn circumference, ear (length and width), neck length, dewlap length, chine length, loin length, rump (length and width), length below knee, hoof circumference, tail and switch length. Results showed that farming systems significantly affect most of the morphological characteristics of both sexes, particularly the morphometric measurements with tall and leggy conformation for TFS cows and bulls. This indicates an adaptation to long distance transhumance and mountain terrain grazing. It can be concluded that the Achai has the potential to adapt to the requirements of specific farming systems. There is hence a need for the conservation of its adaptive traits in both farming systems.
\end{abstract}

Keywords: Achai cattle, morphological characterization, sedentary farming system, transhumant farming system

\begin{abstract}
Resumen
Pese a ser una raza bovina muy bien adaptada a las condiciones montañosas del macizo Hindu Kush en el norte de Pakistán, el ganado Achai sigue siendo un gran desconocido a día de hoy. La raza Achai es criada bajo un sistema ganadero estante (SGE) y un sistema ganadero trashumante (SGT). Este artículo compara las características morfológicas (físicas y morfométricas) de esta raza bovina bajo ambos sistemas ganaderos para conocer el efecto de estos tipos de manejo. Los datos fueron recogidos en 108 hembras adultas y 108 machos del SGE y en 108 hembras y 36 machos del SGT. Se tomaron datos de características físicas (color de la capa, de los cuernos, de las pestañas, del hocico, de las pezuñas y de la punta de la cola) y medidas morfométricas (perímetro torácico, longitud corporal, altura a la cruz, altura a la grupa, longitud de la cara, longitud y circunferencia de los cuernos, longitud y anchura de las orejas, longitud del cuello, longitud de la papada, longitud del tronco, longitud de los lomos, longitud y anchura de la grupa, longitud bajo las rodillas, circunferencia de las pezuñas, longitud de la cola y del mechón de pelo final). Los resultados mostraron que el sistema ganadero afecta significativamente a la mayoría de las características morfológicas de ambos sexos, en especial a las medidas morfométricas. Así, vacas y toros del SGT son animales altos con patas largas. Esta conformación refleja una adaptación a trashumancias de larga distancia y a un pastoreo en terrenos montañosos. Se puede concluir que el ganado Achai tiene potencial de adaptación a las necesidades de sistemas ganaderos específicos. Existe por tanto la necesidad de conservar los rasgos adaptativos de ambos sistemas de explotación.
\end{abstract}

Palabras clave: ganado bovino Achai, caracterización morfológica, sistema ganadero estante, sistema ganadero trashumante

\section{Résumé}

Bien qu'elle soit une race bovine bien adaptée aux conditions montagneuses de la chaîne Hindu Kush du nord du Pakistan, la race Achai demeure encore de nos jours assez inconnue. Ces animaux sont élevés selon un système d'élevage sédentaire (SES) et un système d'élevage transhumant (SET). Cet article compare les caractéristiques morphologiques (physiques et morphométriques) de cette race bovine élevée selon les deux systèmes d'exploitation pour connaître l'effet de ces pratiques d'élevage. Les données ont été prélevées sur 108 femelles adultes et 108 mâles en SES et 108 femelles et 36 mâles en SET. Les suivantes caractéristiques physiques ont été évaluées: couleur de la robe, des cornes, des cils, du museau, des sabots et de la mèche de la queue, et les suivantes mesures morphométriques ont été prises: périmètre thoracique, longueur du corps, hauteur au garrot, hauteur à la croupe, longueur de la tête, longueur et circonférence des cornes, longueur et largeur des oreilles, longueur du cou, longueur du fanon, longueur du tronc, longueur de l'échine, longueur et largeur de la croupe, longueur sous le genou, circonférence des sabots, longueur de la

Correspondence to: M. Saleem, Directorate General (Extension) Livestock and Dairy Development Khyber Pakhtunkhwa, Peshawar, Pakistan. email: saleemtalash@yahoo.com 
queue et de la mèche finale. Les résultats ont montré que les systèmes d'élevage affectent de façon significative la plupart des caractéristiques morphologiques aussi bien des mâles que des femelles, l'effet étant particulièrement significatif pour les mesures morphométriques. Ainsi, il a été noté que les vaches et les taureaux du SET sont de grands animaux à longues pattes. Ceci reflète une adaptation à des transhumances sur de longues distances et au pâturage en terrain montagneux. Il peut être conclu que les bovins Achai ont du potentiel pour s'adapter aux besoins de systèmes d'élevage spécifiques. La conservation de ses traits adaptatifs s'avère donc nécessaire dans les deux systèmes d'élevage.

Mots-clés: bovins Achai, caractérisation morphologique, système d'élevage sédentaire, système d'élevage transhumant

Submitted 22 July 2012; accepted 19 November 2012

\section{Introduction}

It is increasingly recognized that the use, development and conservation of livestock biodiversity are of great importance to food security, rural development and the environment (Pilling et al., 2008). Phenotypic characterization of the indigenous livestock breeds is critical in breed improvement and conservation (Jing et al., 2010; Kugonza et al., 2011). The Achai is an as yet undocumented but well-adapted indigenous cattle breed of the Hindu Kush Mountains in northern Pakistan (Saleem et al., 2012). It is a dairy and light draught breed that can thrive under scarce fodder availability, and it can produce adequately under a hilly and sub-hilly subsistence production setup (Khan et al., 2008). The Achai grazes freely, is resistant to diseases and is better adapted to high altitude areas, and has a better efficiency index than all other cattle breeds of Pakistan, except Jersey crosses and Sahiwal (Kenyanjui and Sheikh-Ali, 2009). Achai cows also have a better reproductive performance than other cattle breeds in Pakistan (Saleem et al., 2012).

Though the official livestock census (Anonymous, 2006) has reported the total population to be 0.59 million with 55 percent concentration in Hindu Kush Mountains, however, these figures include all the non-descript crosses having some resemblance to Achai breed. We estimate the population of phenotypically true Achai breed to be no more than 0.15 millions. This population is limited to the less accessible Hindu Kush Mountain valleys, where the agro-pastoralists still depends on Achai bulls to plough the narrow mountain terraces and hence can afford keeping Achai bull for plough as well as breeding. In these areas the average herd size of Achai cattle is four and seven animals in sedentary farming system (SFS) and transhumant farming system (TFS), respectively (Saleem et al., 2012).

Owing to its important role in the future, the public sector in Khyber Pakhtunkhwa has recently initiated an Achai cattle conservation programme (Khan et al., 2008). However, such conservation programmes remain ineffective because of the lack of scientific information on phenotypically pure Achai cows and bulls (Yakubu et al., 2010). The current investigation shall thus fill this gap while providing the crucial information needed to establish efficient conservation efforts. The generated information will also help breeders to select better animals to keep the breed in its best condition for subsisting in remote mountains. This will insure food security for the poorest segments of Pakistani society living in the Hindu Kush Mountain region.

\section{Material and methods}

\section{Study area}

The broader home tract of the Achai cattle is spread over the northwestern Hindu Kush Mountains of the Khyber Pukhtunkhwa province in Pakistan. SFS are distributed over the mountain and rain-fed areas of the province. For the current study, the district of Lower Dir was taken as the study area for SFS $\left(34^{\circ} 37^{\prime}\right.$ to $35^{\circ} 07^{\prime} \mathrm{N}$ and $71^{\circ} 31^{\prime}$ to $72^{\circ} 14^{\prime} \mathrm{E}$ ), with a mild, temperate climate, 700-1000 mm annual rainfall and 42 to 70 percent relative humidity (Anonymous, 1999). The SFS study area includes the mountainous Talash, Jandool and Maidan valleys (Figure 1). Under TFS, Achai herders spend summers in the uplands of Swat, Dir and Indus Kohistan, and winters in the major sugarcane growing lowlands of the Peshawar valley. The TFS involving transhumance between the Gabral uplands of Swat and the Mardan lowlands was taken as a representative area for the study (Figure 1). The Gabral valley lies between $35^{\circ} 20^{\prime}$ and $35^{\circ} 48^{\prime} \mathrm{N}$ and $72^{\circ} 12^{\prime}$ and $72^{\circ} 32^{\prime} \mathrm{E}$, with a typical dry temperate zone climate (Hamayun, Afzal and Khan, 2006). The Mardan lowlands lay between $34^{\circ} 12^{\prime} 0 \mathrm{~N}$ and $72^{\circ} 1^{\prime} 60 \mathrm{E}$, and has a temperature range from 2.1 to $41.5^{\circ} \mathrm{C}$, an average rainfall of $524.40 \mathrm{~mm}$ and humidity of 73 percent.

\section{Attributes of the farming systems}

The seasonal feeding in SFS is known as a cut-and-carry system, which provides wheat straw, weed thinning and hay in spring; wheat straw, tree leaves and hay in summer; wheat straw, maize stalks and weed thinning in fall; and wheat straw, maize stalks and hay in winter. Farmers also graze their cows on stubble fields (Saleem et al., 2012). For TFS at Gabral (upland), the herders take dry cows, heifers and bulls to the high pastures for grazing, and keep milking cows at the settlements in the valley bottoms for homestead use. Milking cows are taken for grazing daily 
Source: Election Commission of Pakistan ex-NWFP and Provincia

Assembly Constituencies. Boundaries and names shown on this map

do not imply official endorsement or acceptance

by any state or organization

Map and layout: Henri Rueff and Muhammad Saleem 2012

Sketch: Muhammad Saleem, Inam ur Rahim and Saleem Khan 2012

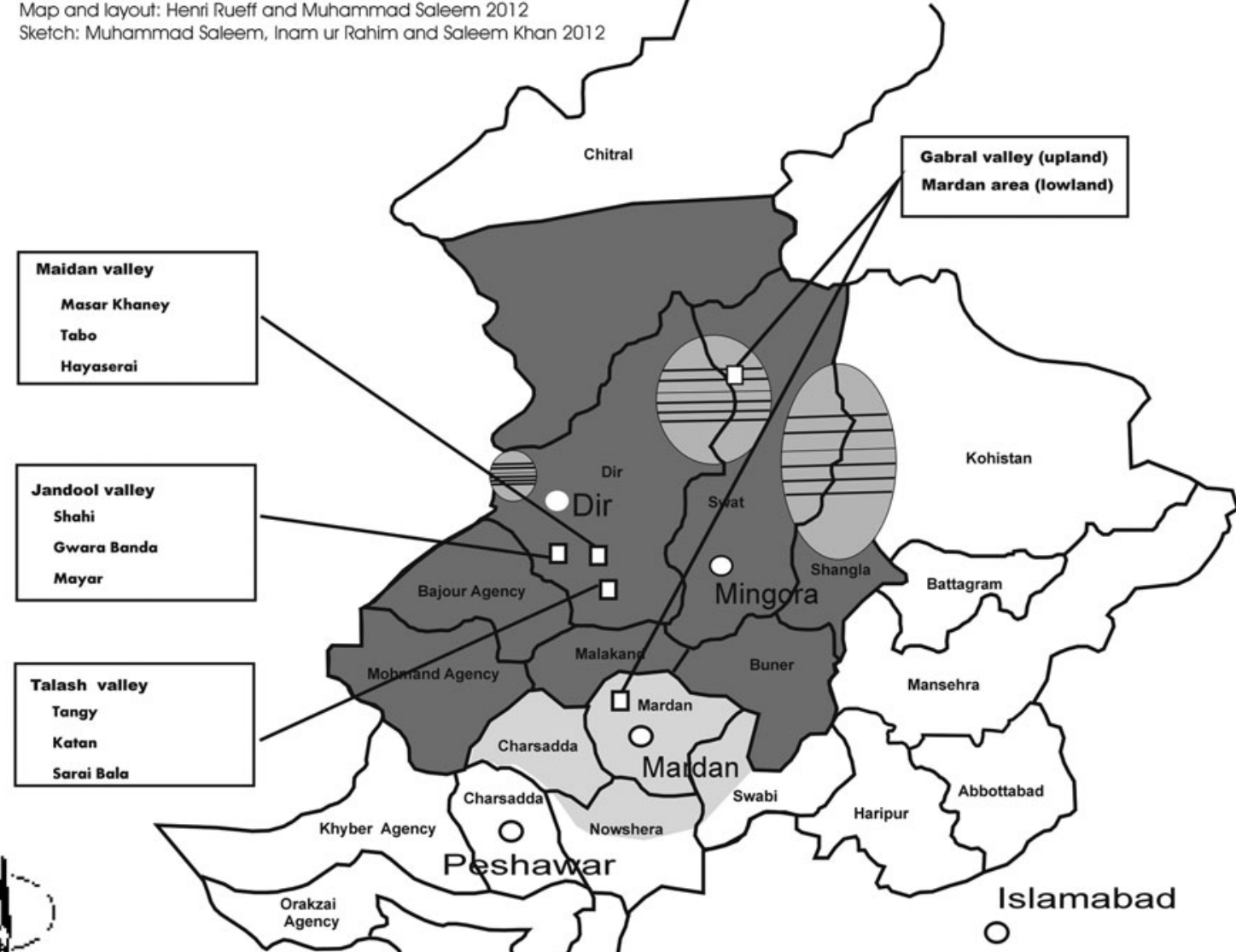

$50 \mathrm{~km}$
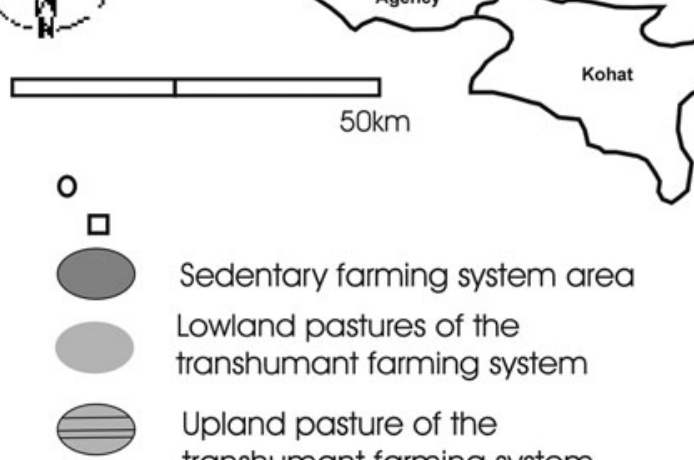

O

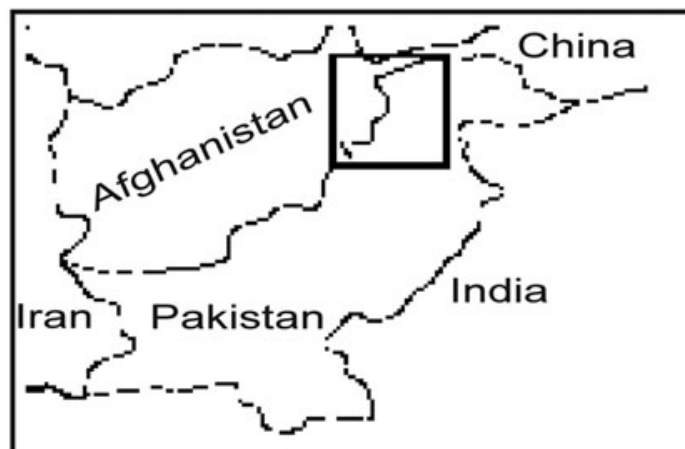

\section{Main cities (district headquarter)}

Figure 1. Map of the study area and locations of the villages where adult Achai cows and bulls were sampled.

to the hillsides near the settlements. In the lowlands, sugarcane tops and maize stover are given during winter, and are complemented with grazing along the canal sides and on stubble fields. The breeding season spreads over the entire year. However, the majority of cows come into heat during summer. In uplands and lowlands, cows are served with the available Achai bulls (Saleem et al., 2012).

\section{Sampling pattern}

The sampling pattern for the study in SFS and TFS is presented in Table 1.
Sedentary farming system

Three villages each from the Talash, Jandool and Maidan valleys in the Lower Dir district were randomly selected. From each village, 12 adult Achai cows and 12 adult Achai bulls were then randomly sampled.

Transhumant farming system

Three settlements were randomly selected in the Gabral valley where 36 adult Achai cows and 12 adult Achai bulls were observed at each settlement for physical and morphometric characteristics. 
Table 1. Sampling pattern of adult Achai cows and bulls in SFS and TFS.

\begin{tabular}{lllcr}
\hline Management & Valley & $\begin{array}{c}\text { Village/ } \\
\text { settlement }\end{array}$ & $\begin{array}{c}\text { Number } \\
\text { of cows }\end{array}$ & $\begin{array}{c}\text { Number } \\
\text { of bulls }\end{array}$ \\
\hline \multirow{2}{*}{ SFS } & Talash & Tangey & 12 & 12 \\
& & Katan & 12 & 12 \\
& Jandool & Sarai Bala & 12 & 12 \\
& & Shahi & 12 & 12 \\
& & Gwarabanda & 12 & 12 \\
& Maidan & Mayar & 12 & 12 \\
& & Masar & 12 & 12 \\
& & Khaney & & 12 \\
& & Tabo & 12 & 12 \\
& Total & Haya serai & 12 & 108 \\
& Gabs & Ghwai Bela & 36 & 12 \\
& & Gul Abad & 36 & 12 \\
& & Karin & 36 & 12 \\
& Total & & 108 & 36 \\
\hline
\end{tabular}

Physical characteristics like colour of the coat, horns, eyelashes, muzzle, hooves and switch were recorded for each animal, and morphometric measurements including heart girth, body length, height at withers, height at hipbone, face length, horn length (along the greater and smaller curvature), horn circumference (at base, mid and tip), ear (length and width), neck (length and circumference), dewlap (length and circumference), chine length, loin length, rump (length and width), length below knee, hoof circumference, tail length and switch length were carried out with the help of measuring tape according to the Food and Agriculture Organization's (FAO) standard procedure (FAO, 1986). Body weight was estimated according to Shaffer's method as described by Al-Amin et al. (2007).

\section{Statistical analysis}

Chi-square test and Student's $t$-test was used to study the effect of a farming system (SFS, TFS) on physical and morphometric characteristics respectively performed in GraphPad Prism-5 software (GraphPad Software, San Diego, CA, USA).

\section{Results}

\section{Physical characteristics}

Physical characteristics of Achai cows and bulls in SFS and TFS are presented in Table 2 .

The dominant coat colour of the cows and bulls in both farming systems is spotted reddish-brown (Figures 2 and 3). However, the farming system significantly $(P<0.05)$ affects the coat colour of Achai cows, with a higher percentage of spotted reddish-brown colour Achai cows in TFS as compared with SFS. Significant variations in the distribution of the colour of eyelashes $(P<0.05)$, muzzle $(P<0.01)$ and switch $(P<0.01)$ of the Achai cow were also observed between SFS and TFS. In the case of bulls, significant variations were observed only in the prevalence of the colour of the horn $(P<0.01)$ and the switch $(P<0.05)$ of the tail between the two systems.

\section{Morphometric measurements and adult body weight}

Morphometric measurements and body weight of Achai cows and bulls in SFS and TFS are shown in Table 3.

Table 2. Physical characteristics of Achai cows and bulls in SFS and TFS.

\begin{tabular}{|c|c|c|c|c|c|c|c|}
\hline \multirow[t]{2}{*}{ Colour } & \multirow[t]{2}{*}{ Description (\%) } & \multicolumn{2}{|c|}{ Cow } & \multirow[b]{2}{*}{ Significance } & \multicolumn{3}{|c|}{ Bull } \\
\hline & & $\begin{array}{c}\text { SFS } \\
n=108\end{array}$ & $\begin{array}{c}\text { TFS } \\
n=108\end{array}$ & & $\begin{array}{c}\text { SFS } \\
n=108\end{array}$ & $\begin{array}{c}\text { TFS } \\
n=36\end{array}$ & Significance \\
\hline \multirow[t]{2}{*}{ Coat } & Spotted reddish brown & 59.26 & 72.22 & * & 66.67 & 68.57 & NS \\
\hline & Solid reddish brown & 40.74 & 27.78 & & 33.33 & 31.43 & \\
\hline \multirow[t]{4}{*}{ Horn } & Light brown with greyish black tip & 44.44 & 25.93 & NS & 31.48 & 8.57 & $* *$ \\
\hline & Light brown with blackish tinge in the upper part & 28.70 & 36.11 & & 49.07 & 14.29 & \\
\hline & Light brown & 26.85 & 20.37 & & 14.81 & 62.86 & \\
\hline & Black & - & 17.59 & & 4.63 & 14.29 & \\
\hline \multirow[t]{3}{*}{ Eyelashes } & Red & 76.85 & 62.04 & $*$ & 77.78 & 80 & NS \\
\hline & Black & 21.30 & 27.78 & & 17.59 & 8.57 & \\
\hline & White & 1.85 & 10.19 & & 4.63 & 11.43 & \\
\hline \multirow[t]{3}{*}{ Muzzle } & Light brown & 36.11 & 17.59 & $* *$ & 18.52 & 25.71 & NS \\
\hline & Light brown with black pigments & 50.93 & 53.70 & & 50.92 & 45.71 & \\
\hline & Black & 12.96 & 28.70 & & 30.56 & 28.57 & \\
\hline \multirow[t]{3}{*}{ Hoof } & Light brown & 56.48 & 40.74 & NS & 31.48 & 48.57 & NS \\
\hline & Black & 31.48 & 39.81 & & 50.92 & 31.43 & \\
\hline & Light brown with black striations & 12.04 & 19.44 & & 17.59 & 20.00 & \\
\hline \multirow[t]{3}{*}{ Switch } & Reddish brown & 55.56 & 22.22 & $* *$ & 32.41 & 45.71 & $*$ \\
\hline & White & 35.18 & 66.67 & & 45.37 & 51.43 & \\
\hline & Black & 9.26 & 11.11 & & 22.22 & 2.86 & \\
\hline
\end{tabular}

$\mathrm{NS}=$ not significant.

$* P<0.05 ; * * P<0.01$. 


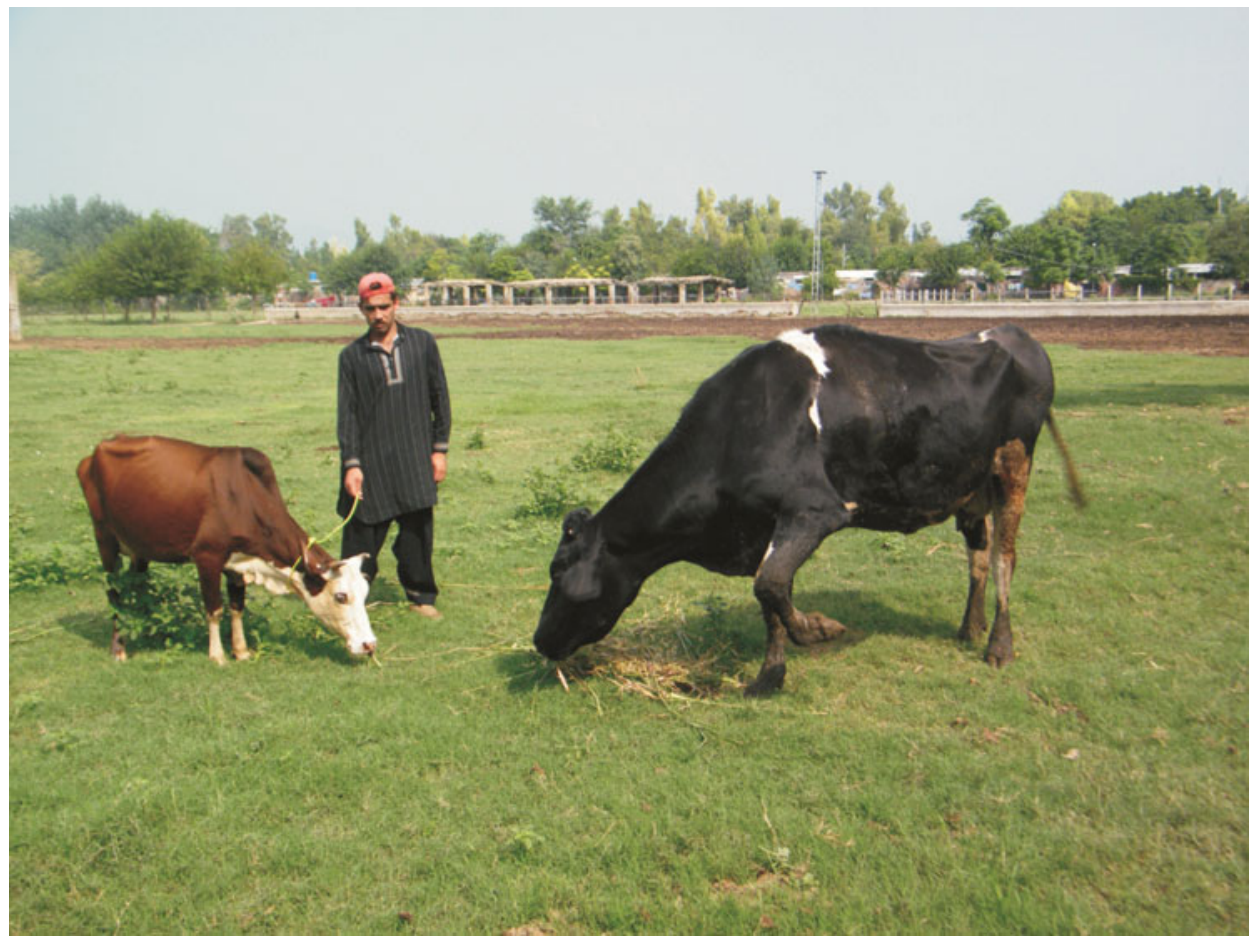

Figure 2. Spotted reddish brown Achai (left) with Friesian cow (right) in SFS.

Achai cows in TFS have significantly higher values for most of the morphometric measurements and adult body weight than do Achai cows in SFS, except chine and loin length, which were significantly longer in SFS cows. There was no significant difference in horn length, ear length and width and height below the knee joint between Achai cows in SFS and TFS.

Achai bulls in SFS have significantly larger heart girth size, longer bodies, longer and thicker horns, long neck,

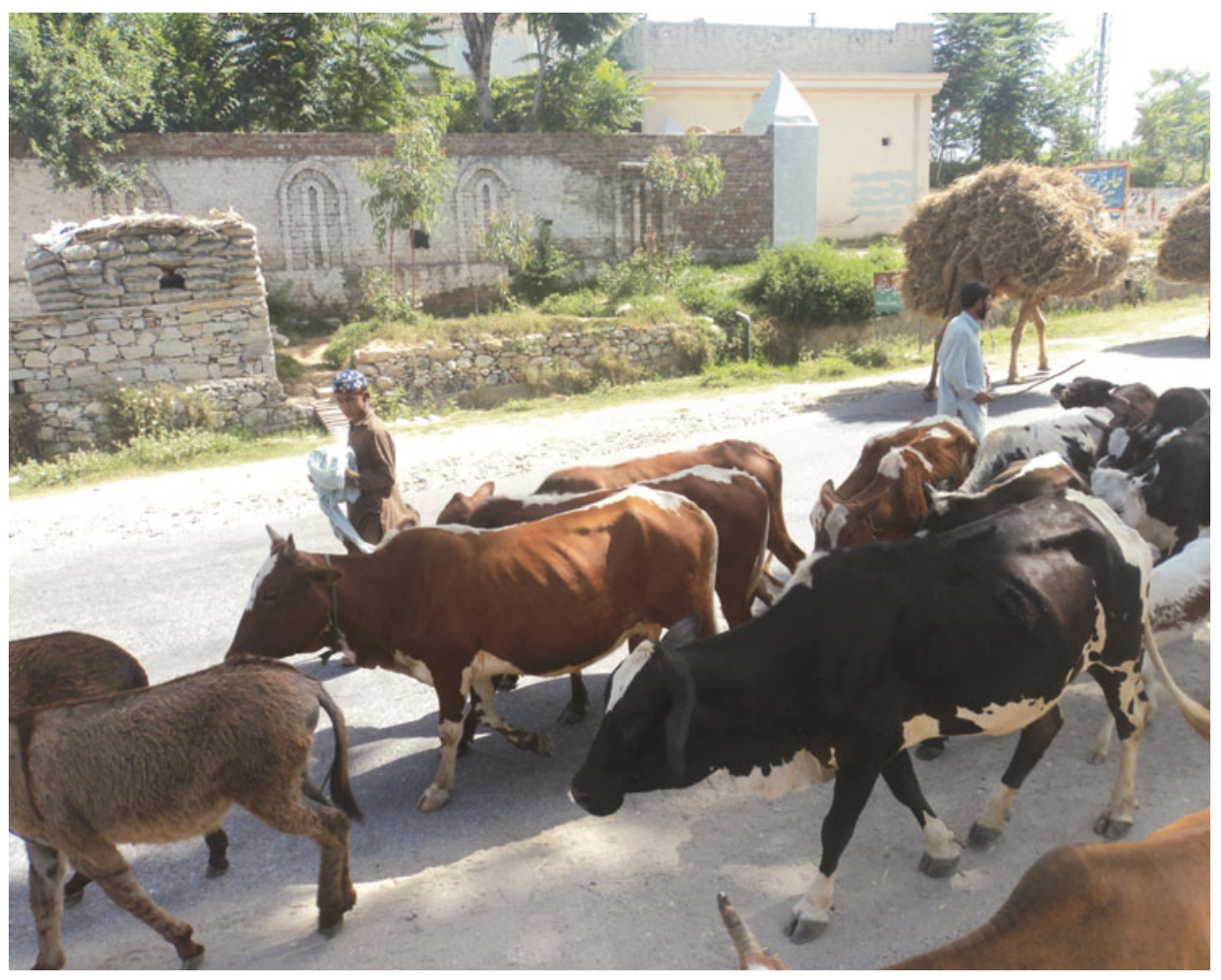

Figure 3. Spotted reddish brown Achai cows in a transhumant cattle herd in TFS. 
Table 3. Mean values $( \pm$ SEM) of morphometric measurements $(\mathrm{cm})$ and adult body weight $(\mathrm{kg})$ of Achai cows and bulls in SFS and TFS.

\begin{tabular}{|c|c|c|c|c|}
\hline \multirow[t]{2}{*}{ Variables } & \multicolumn{2}{|c|}{ Cows } & \multicolumn{2}{|c|}{ Bulls } \\
\hline & SFS & TFS & SFS & TFS \\
\hline Heart girth & $134.33 \pm 0.6$ & $138.60 \pm 0.64^{\mathrm{a}^{* *}}$ & $140.50 \pm 1.1$ & $134.12 \pm 1.9^{\mathrm{b}^{* *}}$ \\
\hline Body length & $112.20 \pm 0.7$ & $116.11 \pm 0.71^{\mathrm{a}^{* *}}$ & $116.26 \pm 1.0$ & $112.12 \pm 1.85^{\mathrm{b}^{*}}$ \\
\hline Height at withers & $101.80 \pm 0.4$ & $103.69 \pm 0.53^{\mathrm{a}^{* *}}$ & $107.62 \pm 0.6$ & $106.88 \pm 1.1^{\mathrm{NS}}$ \\
\hline Height at hipbone & $100.79 \pm 0.3$ & $102.48 \pm 0.52^{\mathrm{a}^{* *}}$ & $106.38 \pm 0.4$ & $106.09 \pm 0.7^{\mathrm{NS}}$ \\
\hline Face length & $41.27 \pm 0.27$ & $42.57 \pm 0.20^{\mathrm{a}^{* *}}$ & $41.93 \pm 0.26$ & $42.48 \pm 0.46^{\mathrm{NS}}$ \\
\hline Horn greater curvature length & $17.37 \pm 0.42$ & $17.72 \pm 0.46^{\mathrm{NS}}$ & $19.73 \pm 0.57$ & $16.45 \pm 0.99^{\mathrm{b}^{* *}}$ \\
\hline Horn small curvature length & $12.92 \pm 0.34$ & $13.81 \pm 0.36^{\mathrm{NS}}$ & $16.09 \pm 0.44$ & $13.04 \pm 0.77^{\mathrm{b**}}$ \\
\hline Horn base circumference & $11.86 \pm 0.15$ & $12.82 \pm 0.22^{\mathrm{a}^{* *}}$ & $16.75 \pm 0.20$ & $15.94 \pm 0.54^{\mathrm{b}^{*}}$ \\
\hline Horn mid circumference & $9.66 \pm 0.19$ & $10.56 \pm 0.16^{\mathrm{a}^{* *}}$ & $14.66 \pm 0.24$ & $12.6 \pm 0.41^{\mathrm{b}^{* *}}$ \\
\hline Horn tip circumference & $5.22 \pm 0.14$ & $5.22 \pm 0.08^{\mathrm{NS}}$ & $6.25 \pm 0.15$ & $5.88 \pm 0.26^{\mathrm{NS}}$ \\
\hline Ear length & $17.99 \pm 0.21$ & $16.56 \pm 0.15^{\mathrm{NS}}$ & $16.14 \pm 0.15$ & $16.59 \pm 0.26^{\mathrm{NS}}$ \\
\hline Ear width & $11.59 \pm 0.15$ & $12.09 \pm 0.11^{\mathrm{NS}}$ & $10.79 \pm 0.11$ & $11.34 \pm 0.19^{\mathrm{NS}}$ \\
\hline Neck length & $34.92 \pm 0.52$ & $30.95 \pm 0.37^{\mathrm{a}^{* *}}$ & $33.22 \pm 0.55$ & $30.26 \pm 0.97^{\mathrm{b} * *}$ \\
\hline Dewlap length & $67.11 \pm 1.02$ & $72.21 \pm 0.95^{\mathrm{a}^{* *}}$ & $76.38 \pm 0.97$ & $71.15 \pm 1.7^{\mathrm{b}^{* *}}$ \\
\hline Chine length & $36.81 \pm 0.37$ & $33.08 \pm 0.26^{\mathrm{a}^{* *}}$ & $39.66 \pm 0.46$ & $34.96 \pm 0.8^{\mathrm{b}^{* *}}$ \\
\hline Loin length & $33.28 \pm 0.45$ & $31.37 \pm 0.26^{\mathrm{a}^{* *}}$ & $29.44 \pm 0.26$ & $28.74 \pm 0.45^{\mathrm{NS}}$ \\
\hline Rump length & $30.92 \pm 0.38$ & $36.04 \pm 0.19^{\mathrm{a}^{* *}}$ & $33.45 \pm 0.29$ & $33.2 \pm 0.52^{\mathrm{NS}}$ \\
\hline Rump width & $30.55 \pm 0.27$ & $32.00 \pm 0.18^{\mathrm{a}^{* *}}$ & $27.72 \pm 0.28$ & $28.72 \pm 0.49^{\mathrm{NS}}$ \\
\hline Length below knee & $26.93 \pm 0.31$ & $26.95 \pm 0.14^{\mathrm{NS}}$ & $27.94 \pm 0.15$ & $28.67 \pm 0.26^{\mathrm{b}^{*}}$ \\
\hline Hoof circumference & $27.94 \pm 0.36$ & $33.49 \pm 0.22^{\mathrm{a}^{* *}}$ & $33.49 \pm 0.19$ & $32.91 \pm 0.33^{\mathrm{NS}}$ \\
\hline Tail length & $78.81 \pm 1.03$ & $91.04 \pm 0.79^{\mathrm{a}^{* *}}$ & $95.06 \pm 0.66$ & $89.39 \pm 1.16^{\mathrm{b} * *}$ \\
\hline Switch length & $21.65 \pm 0.89$ & $30.99 \pm 0.61^{\mathrm{a}^{* *}}$ & $32.44 \pm 0.5$ & $30.30 \pm 0.88^{\mathrm{b}^{*}}$ \\
\hline Body weight & $188.23 \pm 2.6$ & $207.13 \pm 2.59^{\mathrm{a}^{*}}$ & $215.83 \pm 4.9$ & $190.32 \pm 8.20^{\mathrm{b}^{*}}$ \\
\hline
\end{tabular}

${ }^{\mathrm{a}, \mathrm{b}}$ Means with different superscript letters in the same row for the same sex differ significantly between SFS and TFS.

NS $=$ not significant.

$* P<0.05 ; * * P<0.01$

dewlap, chine, tail and switch and adult body weight than TFS Achai bulls. Achai bulls in TFS only have a significantly higher value for height below knee joint. There were no significant differences for the rest of the body measurements.

\section{Discussion}

Variation in coat colour in cattle depends upon geographical and climatic features and is reinforced by herder's preferences (Seo et al., 2007; Desta, Ayalew and Hedge, 2011). The spotted reddish-brown coat colour of Achai cows and bulls in SFS and TFS may be due to the similar environmental condition in both farming system. However, the significantly $(P<0.05)$ higher percentage of spotted reddish-brown coat coloured cows in TFS could be due to the preference of the transhumant herders for this type of cows owing to better productivity. Such preference for spotting colour pattern has not been observed in SFS. Kugonza et al. (2012) also reported coat colour as the most important selection criteria among physical characteristics by the pastoralists rearing Ankole cattle in Uganda. In the case of bulls, the significant $(P<0.01)$ variations in the prevalence of horn colour between SFS and TFS may also be due to the herders' preference for light brown colour in TFS. In SFS, the herders give more attention to body frame followed by horn colour and orientation. Wurzinger et al. (2006) and Kugonza et al. (2012) also considered horn colour and shape as the most important phenotypic features among the physical characteristics, followed by coat colour, all of which are used as selection criteria in bulls as compared with cows.

Various morphometric measurements have been identified as the most appropriate variables to discriminate between and within cattle breeds (Mwacharo et al., 2006; Yakubu et al., 2010). Within the breed variation in morphometric measurements reflect adaptation to the specific production system (Hall, 1998; Kugonza et al., 2011).

The significantly higher values (Table 2) for most of the morphometric measurements of Achai cows in TFS than Achai cows in SFS seem to be an adaptation to TFS, where tall (height at withers) and large body size (heart girt and body length) are suitable for trekking long distances to water and grazing points (Hall, 1998; Mwacharo et al., 2006). Kugonza et al. (2011) also recorded significantly larger body dimensions for Ankole cattle in a pastoral system as compared with a crop-livestock production system.

Achai bulls in TFS have significantly lower values for most of the body measurements than Achai bulls in SFS, except for length below the knee joint, which was significantly higher for TFS bulls (Table 2). This could be an adaptation to mountain terrain grazing as the taller and 
Table 4. Comparison of morphometric measurements $(\mathrm{cm})$ of Achai cattle in SFS and TFS with other cattle breeds of Pakistan.

\begin{tabular}{|c|c|c|c|c|c|c|}
\hline Breed & & Sex & Heart girth & Body length & Height at wither & Source \\
\hline Achai & SFS & Cow & $134.33 \pm 0.60$ & $112.20 \pm 0.77$ & $101.80 \pm 0.42$ & Present study \\
\hline \multirow[t]{3}{*}{ Achai } & TFS & Bull & $140.50 \pm 1.12$ & $116.26 \pm 1.02$ & $107.62 \pm 0.68$ & \\
\hline & & Cow & $138.60 \pm 0.64$ & $116.11 \pm 0.71$ & $103.69 \pm 0.53$ & \\
\hline & & Bull & $134.12 \pm 1.97$ & $112.12 \pm 1.85$ & $106.88 \pm 1.16$ & \\
\hline \multirow[t]{2}{*}{ Lohani } & & Cow & $139.78 \pm 1.58$ & $114.96 \pm 0.79$ & $111.84 \pm 1.07$ & Joshi and Phillips (1953) \\
\hline & & Bull & $160.02 \pm 2.06$ & $129.11 \pm 3.05$ & $121.92 \pm 1.65$ & \\
\hline \multirow[t]{2}{*}{ Rojhan } & & Cow & 152.40 & 124.46 & 106 & Shah (1953) \\
\hline & & Bull & 163.83 & 134.62 & 120.65 & \\
\hline \multirow[t]{2}{*}{ Dhanni } & & Cow & 142 & 137 & 119 & Khan, Younas \& Hanjra (1982) \\
\hline & & Bull & 182 & 162 & 132 & \\
\hline \multirow[t]{2}{*}{ Sahiwal } & & Cow & 167 & 135 & 120 & Khan, Younas \& Hanjra (1982) \\
\hline & & Bull & 200 & 160 & 136 & \\
\hline \multirow{2}{*}{ Red Sindhi } & & Cow & 155 & 127 & 115 & Khan, Younas \& Hanjra (1982) \\
\hline & & Bull & 185 & 145 & 132 & \\
\hline \multirow[t]{2}{*}{ Tharparker } & & Cow & $165.66 \pm 1.35$ & $133.25 \pm 0.84$ & $126.24 \pm 1.04$ & Joshi and Phillips (1953) \\
\hline & & Bull & $184.66 \pm 1.60$ & $139.95 \pm 1.24$ & $130.81 \pm 0.99$ & \\
\hline \multirow{2}{*}{ Bhagnari } & & Cow & $169.15 \pm 2.34$ & $134.11 \pm 1.02$ & $129.54 \pm 064$ & Wahid (1975) \\
\hline & & Bull & $189.74 \pm 1.80$ & $156.03 \pm 0.94$ & $145.64 \pm 0.68$ & \\
\hline \multirow[t]{2}{*}{ Dajal } & & Cow & 205 & 145 & 136 & Khan, Younas \& Hanjra (1982) \\
\hline & & Bull & 167 & 137 & 126 & \\
\hline
\end{tabular}

leggier animals are more suitable for grazing in steep and rugged terrains than short-legged animals (Mwacharo et al., 2006). The Achai bulls in TFS also have significantly $\left(t_{(141)}=2.55 ; P<0.01\right)$ shorter body length to height at withers ratio than bulls in SFS $(1.05 \pm 0.01$ and $1.08 \pm$ 0.01 , respectively), which indicates that TFS bulls are taller with respect to body length than SFS bulls. This sort of morphological feature is best suited to draught power in rocky mountains (Berthouly et al., 2010).

The smaller body size of Achai cattle among all the cattle breeds of Pakistan, as indicated by the smaller heart girth, body length and height at wither (Table 4), seems to be an adaptive trait for survival during seasonal fodder fluctuation. This is because smaller animals are reported to be less susceptible to fodder shortages (Hall, 1998), and they can move more easily and quickly (Ouma et al., 2004) on mountain slopes for grazing.

\section{Conclusion}

Because of the diversity of the Achai cattle production system, it has developed diverse morphological characteristics that suit mobility and draughtability in rugged mountain terrain, as well as better reproductive and productive performance under scarce fodder availability. These characteristics make it an ideal breed that can insure food security, particularly in relation to the changing climate that is predicted in the Hindu Kush and Himalayan regions (Hussain et al., 2005). Our findings contribute to the basic information that characterizes this breed, and is relevant as a source of essential information to support the selection and conservation programmes of the Achai cattle breed under both SFS and TFS. However, comprehensive research is needed to find out the breeding goals of the relevant farming systems through which an in situ conservation can be made.

\section{Acknowledgements}

This study was conducted within the framework of the Joint Research Partnership funded by the Swiss National Science Foundation (SNSF) and the Swiss Agency for Development and Cooperation (SDC). It was also conducted within the framework of the Swiss National Centre of Competence in Research (NCCR) NorthSouth: Research Partnerships for Mitigating Syndromes of Global Change. The NCCR North-South is co-funded by SNSF and SDC, and the participating institutions.

\section{References}

Al-Amin, M., Nahar, A., Bhuiyan, A.K.F.H. \& Faruque, M.O. 2007. On-farm characterization and present status of North Bengal Grey (NBG) cattle in Bangladesh. Anim. Genet. Resourc. Inf., 40: 55-64.

Anonymous. 1999. District Census Report of District Lower Dir. Census Publication No. 31. Islamabad, Population Census Organization, Statistics Division, Government of Pakistan.

Anonymous. 2006. Livestock Census, NWFP. Lahore, Pakistan, Agricultural Census Organization, Statistics Division, Government of Pakistan, Gurumangat Road, Gulberg-III.

Berthouly, C., Maillard, J.C., Phan, D.L., Nhu, V.T., Bed'Hom, B., Leroy, G., Hoang, T.H., Laloe, D., Bruneau, N., Vu, C.C., Nguyen, D.V., Verrier, E. \& Rognon, X. 2010. Revealing fine scale subpopulation structure in the Vietnamese H'mong cattle breed for conservation purposes. Biomed. Central Genet. 11: 45. (available at http://www.biomedcentral.com/1471-2156/11/45).

Desta, T.T., Ayalew, W. \& Hedge, B.P. 2011. Breed and trait preferences of Sheko cattle keepers in southern Ethiopia. Trop. Anim. Health Prod. 43: 851-856. 
FAO. 1986. Animal Genetic Resources Data Banks. 2. Descriptor List for Cattle, Buffalo, Pigs, Sheep and Goats. FAO Animal Production and Health Paper 59/2. Rome, Food and Agriculture Organization of the United Nations. (available at: www.fao.org/docrep/009/ ah760e/ah760e00.htm

Hall, S.J.G. 1998. Traditional livestock in semi-arid North Eastern Zimbabwe: Mashona cattle. Trop. Anim. Health Prod. 30: 351-360.

Hamayun, M., Afzal, S. \& Khan, M.A. 2006. Ethnopharmacology, indigenous collection and preservation techniques of some frequently used medicinal plants of Utror and Gabral, district Swat, Pakistan. Afr. J. Trad. Complem. Alter. Med. 3: 57-73.

Hussain, S.S., Mudassar, M., Sheikh, M.M. \& Manzoor, N. 2005 Climate change and variability in mountain regions of Pakistan: implications for water and agriculture. Pak. J. Met. 2: 75-90.

Jing, L., Ren-jun, Z., Guo-rong, Z., Quing-ran, Y. \& Hua-ming, M. 2010. Quantitative and qualitative body traits of Longling Yellow goats in China. Agric. Sci. China 9: 408-415.

Joshi, N.R. \& Phillips, R.W. 1953. Zebu cattle of India and Pakistan. FAO-Agricultural Studies No. 19. Rome, Italy, Food and Agriculture Organization of the United Nations.

Kenyanjui, M.B. \& Sheikh-Ali, M. 2009. Observations on cattle dairy breeds in Pakistan; need to curb unseen economic losses through control of mastitis and endemic diseases. J. Agric. Environ. International Dev. 103: 155-172.

Khan, B.B., Younas, M. \& Hanjra, S.H. 1982. Breeds and Types of Livestock in Pakistan. Faisalabad, Department of Livestock Management, University of Agriculture, pp. 6-13.

Khan, M.S., Rehman, Z., Khan, M.A. \& Ahmad, S. 2008. Genetic resources and diversity in Pakistani cattle. Pak. Vet. J. 28: 95-102.

Kugonza, D.R., Nabasirye, M., Mpairwe, D., Hanotte, O. \& Okeyo, A M. 2011. Productivity and morphology of Ankole cattle in three livestock production systems in Uganda. Anim. Genet. Resour. 48: 13-22.

Kugonza, D.R., Nabasirye, M., Hanotte, O., Mpairwe, D. \& Okeyo, A.M. 2012. Pastoralists' indigenous selection criteria and other breeding practices of the long-horned Ankole cattle in Uganda. Trop. Anim. Health Prod. 44: 557-565.

Mwacharo, J.M., Okeyo, A.M., Kamande, G.K. \& Rege, J.E.O. 2006 The small East African shorthorn zebu cows in Kenya. 1: linear body measurements. Trop. Anim. Health Prod. 38: 65-74.

Ouma, E., Abdulai, A., Drucker, A. \& Obare, G. 2004. Assessment of farmer preferences for cattle traits in smallholder cattle production systems of Kenya and Ethiopia. Paper presented at Deutscher Tropentag Conference on International Agricultural Research for Development, October 5-7, Berlin, Germany (available at www.tropentag.de/2004/abstracts/links/Drucker UC2BrqI5.pdf)

Pilling, D., Boerma, D., Scherf, B. \& Hoffmann, I. 2008. Sustaining livestock biodiversity -from assessment to action. Biodiversity 9: $14-18$

Saleem, M., Rahim, I., Rueff, H., Khan, M., Maselli, D., Weismann, U. \& Muhammad, S. 2012. Effect of management on reproductive performances of the Achai cattle in theHindu Kush (Northern Pakistan). Trop. Anim. Health Prod. 44: 1297-1302.

Seo, K., Mohanty, R.T., Choi, T. \& Hwang, I. 2007. Biology of epidermal and hair pigmentation in cattle: a mini review. Vet. Dermat. 18: $392-400$.

Shah, S.I.A. 1953. Breeds of Punjab. Animal Husbandry Department Punjab bulletin No. 5. Lahore, Government Printing Punjab.

Wahid, A. 1975. Livestock Resources of Pakistan: Bhagnari Cattle. Monograph-2, University of Karrachi, Karachi-32, Pakistan.

Wurzinger, M., Ndumu, D., Banumung, R., Drucker, A., Okeyo, A. M., Semambo, D.K., Byamungu, N. \& Solkner, J. 2006. Comparison of production system and selection criteria of Ankole cattle by breeders in Burundi, Rwanda, Tanzania and Uganda. Trop. Anim. Health Prod. 38: 571-581.

Yakubu, A., Idahor, K.O., Haruna, H.S., Wheto, M. \& Amusan, S. 2010. Multivariate analysis of phenotypic differentiation in Bunaji and Sokoto Gudali cattle. Acta. Agric. Solvenica 96: $75-80$ 